\title{
Mineralogical and Chemical Characteristics of Clays Consumed in the District of Abidjan (Côte D’Ivoire)
}

\author{
Vamoussa Coulibaly ${ }^{1 *}$, Joseph Sei ${ }^{1}$, Léon Konan Koffi' ${ }^{1}$, Samuel Oyetola ${ }^{1}$, El-Aïd Jdid ${ }^{2,3}$, \\ Fabien Thomas ${ }^{4,5}$ \\ ${ }^{1}$ Laboratoire de Chimie des Matériaux Inorganiques, UFR SSMT, Université Félix Houphouët-Boigny de \\ Cocody-Abidjan, Abidjan, Côte d'Ivoire \\ ${ }^{2}$ Université de Lorraine, Laboratoire Géoressources-UMR 7359, Rue du Doyen Roubault, Vandœuvre, France \\ ${ }^{3}$ CNRS, Laboratoire Géoressources-UMR 7359, Rue du Doyen Roubault, Vandoeuvre, France \\ ${ }^{4}$ Université de Lorraine, Laboratoire Interdisciplinaire des Environnements Continentaux-UMR 7360, 15 rue \\ du Charmois, Vandœuvre, France \\ ${ }^{5}$ CNRS, Laboratoire Interdisciplinaire des Environnements Continentaux-UMR 7360, 15 rue du Charmois, \\ Vandœuvre, France \\ Email: ${ }^{*}$ coulibaly vamoussa@yahoo.fr
}

Received 22 September 2014; revised 20 October 2014; accepted 12 November 2014

Copyright (C) 2014 by authors and Scientific Research Publishing Inc.

This work is licensed under the Creative Commons Attribution International License (CC BY).

http://creativecommons.org/licenses/by/4.0/

(c) (i) Open Access

\section{Abstract}

Clay materials of the quarry of Bingerville (district of Abidjan) have been characterized by chemical analysis, X-rays diffraction, infrared spectroscopy and thermal analysis. These materials contain kaolinite $(41 \%-84 \%)$, illite $(4 \%-10 \%)$, quartz $(14 \%-27 \%)$, goethite $(2 \%-5 \%)$ and small amount of rutile $(1 \%)$ that are not toxic minerals. They also contain some heavy metals which are beneficial to human biological activity (cobalt, copper, molybdenum, zinc) in tiny quantities. Some other heavy metals (lead, cadmium) which are considered as poisonous for human are present in very low content. The samples characterized by relatively fine grains are moderately crystallized. Their specific surface area varied from 26 to $43 \mathrm{~m}^{2} \cdot \mathrm{g}^{-1}$. The mineralogical and physicochemical characteristics of these samples are like ones known for their healing properties. The consumption by internal way of studied materials, although it may be beneficial, requires a sifting to remove coarse grains $(\phi>2 \mu \mathrm{m})$ and a previous microbiological control.

\section{Keywords}

Mineralogy, Physicochemical Analysis, Kaolinite, Illite, Edibility

\footnotetext{
${ }^{*}$ Corresponding author.
}

How to cite this paper: Coulibaly, V., Sei, J., Koffi, L.K., Oyetola, S., Jdid, E.-A. and Thomas, F. (2014) Mineralogical and Chemical Characteristics of Clays Consumed in the District of Abidjan (Côte D'Ivoire). Materials Sciences and Applications, 5, 1048-1059. http://dx.doi.org/10.4236/msa.2014.514108 


\section{Introduction}

Clay materials are natural products widely used in various domains including construction, ceramics [1], paper [2], breeding [3], pharmaceuticals [4] [5], etc. These multiple uses of clays are due to their properties which are different according to their structure, mineralogical composition and origin.

Particularly, in public health, the clay used as healing material must have fine grain size, high specific surface area, high specific heat, and high adsorption and absorption capacities, while its cooling rate or heat diffusiveness should be low. Clay should also be easy to handle, and give a pleasant sensation when applied directly onto the skin [6]-[8].

In terms of typology, three main groups of natural healing clays can be classified: swelling clay (smectite), illite and kaolinite clays and finally fibrous clays (palygorskite and sepiolite).

Recent investigations showed the antibacterial and bactericidal properties of some clay, based on experiments carried out by [9]-[13], showing the ability to kill a broad spectrum of pathogenic bacteria. One of these bacteria is Mycobacterium ulcerans which causes skin chronic disorder named Buruli ulcer, mostly endemic to central and western Africa. Treated with special clay of bentonite type, the skin lesions or wounds became gradually less acute due to skin tissue regeneration.

In Côte d'Ivoire, clays consumed (especially by pregnant women) for their healing properties, are traditionally prepared and marketed without prior mineralogical and microbiological tests. They are directly ingested or used externally through skin applications.

While this practice provides the consumers a certain well-being, it has drawbacks because these materials, which are generally heterogeneous, may present potential risks for human health, due to toxic minerals or soluble chemical species [14]. Therefore, a better knowledge of the mineralogy and the properties of these materials are critical to prevent risks related to this practice. The aim of the present work is to obtain a comprehensive picture of the mineralogical and chemical composition of samples that are commonly extracted and marketed in the surroundings of Abidjan (Côte d'Ivoire), in order to evaluate their possible negative impact on health.

\section{Materials and Methods}

\subsection{Materials}

The studied clay materials were sampled from the exploited quarry of Bingerville (district of Abidjan, Côte d'Ivoire), located in the Southeast of the sedimentary basin containing clay and sand formations [15]. These materials were taken according to their color, and subjected to the same heat treatment than the marketed materials commonly called "Lokpo". This treatment involves heating and roaster of the samples for 3 to 5 days in an oven powered by firewood. This treatment confers the clay material an appetizing smell and taste.

For the present study, seven samples used were labeled as follows:

LBF: white Lokpo; LJPF: yellow Lokpo; LRF: red Lokpo; LVF: purple Lokpo; LMF: brown Lokpo; LJFF: dark-yellow Lokpo; LNF: black Lokpo.

The materials labeled LBF, LJPF, LRF, LVP and LMF are marketed as “edible”. Conversely, materials LJFF and LNF, probably because of their aspects (color, flavor) are not consumed. The latter were included in this study so as to know if there mineralogy and physicochemical properties are different from the first. For the different analyses the collected samples were dried at $40^{\circ} \mathrm{C}$ during 24 hours in a stove, and ground in a planetary grinder during 1minute.

\subsection{Analytical Methods}

Chemical analysis was performed using a Jobin-Yvon 70P quantometer equipped with a plasma ICP-AES (Inductively Coupled Plasma-Atomic Emission Spectroscopy) for major elements and a Perkin Elmer Elan 5000 equipped with a plasma ICP-MS (Inductively Coupled Plasma-Mass Spectroscopy) for the trace elements. Prior to analysis, samples were mixed with lithium metaborate $\left(\mathrm{LiBO}_{2}\right)$ melted and then dissolved in nitric acid $\left(\mathrm{HNO}_{3}\right)$.

X-Ray diffraction patterns on powders and on oriented preparations were recorded using a D8 Advance Bruker diffractometer equipped with Co K $\alpha$ radiation $(\lambda=1.7890 \AA)$, operating at $35 \mathrm{kV}$ and $45 \mathrm{~mA}$. The diffraction patterns were obtained in a $2 \theta$ angle ranging from $3^{\circ}$ to $64^{\circ}$ at a scanning rate of $1^{\circ} \min ^{-1}$. Oriented 
samples were prepared by extracting the fraction of less than $2 \mu \mathrm{m}$ of the samples by sedimentation, centrifugation of the supernatant and spreading of the centrifugation pellet on a glass slide.

Infrared spectra in the range of wave numbers from 600 to $4000 \mathrm{~cm}^{-1}$ were obtained in the diffuse reflectance mode, using a Infrared Fourrier transformer spectrometer Bruker IFS 55, equipped with a He-Ne laser and a MCT type detector (Mercury telluride and cadmium) broad band $\left(6000-600 \mathrm{~cm}^{-1}\right)$ and high sensitivity. For analysis, the samples $(70 \mathrm{mg})$ were diluted in $\mathrm{KBr}(370 \mathrm{mg})$ and manually ground.

Differential thermal analyses and thermogravimetric analyses were performed using a Setsy SETARAM 24 DTA/TGA equipment, according to a $5^{\circ} \mathrm{C} \cdot \mathrm{min}^{-1}$ temperature increase from room temperature to $1200^{\circ} \mathrm{C}$, under an argon flow.

The particle size distribution was determined using the laser diffraction analyzer Malvern Mastersizer MS 20 analyzing particle sizes between 0.1 and $600 \mu \mathrm{m}$ with an accuracy of $1 \%$ of the median diameter.

The specific surface area was determined by applying the BET method to nitrogen gas adsorption isotherms at $77 \mathrm{~K}$. The adsorption isotherms were recorded on an automatic home-made equipment along with a turbomolecular vacuum group ensuring a dynamic vacuum of $10^{-6} \mathrm{mbar}$, and a 0 - 1000 mbar Edwards pressure gauge. The gas used is nitrogen higher grade quality (purity > 99.995\%) supplied by Alphagaz.

\section{Results and Discussion}

\subsection{Mineralogical Composition of the Clay Samples}

X-ray powder diagrams (Figure 1(a)) showed that samples were mainly composed of kaolinite (7.15 $\AA$ and 3.58 $\AA$ ), illite (9.95 $\AA$ and $4.97 \AA$ ), goethite $(4.15 \AA$ ) and quartz (4.25 $\AA$ and $3.34 \AA$ ). Except sample LJFF, which contained a strong proportion of goethite, the samples showed quite similar mineral composition, the variability of which will be quantified below. Figure $1(b)$ additionally showed that the fine $(<2 \mu \mathrm{m})$ fraction is devoid of quartz and contains mainly kaolinite, and secondly illite and/or goethite.

In the $600-1200 \mathrm{~cm}^{-1}$ range of the infrared spectra (Figure 2(a)), the bands observed at 754 and $792 \mathrm{~cm}^{-1}$ are specific to clays from the kaolinite family and are assigned to $\mathrm{OH}$ bending toward the surface of the clay sheet [16] [17]. In all samples, additional bands less marked are observed at 831 and $876 \mathrm{~cm}^{-1}$. They are respectively characteristic of the deformation vibration of Al-OH-Fe and Fe-OH-Fe [18] following the substitution of aluminium by iron (structural iron) in the kaolinite structure. The bands observed at 914 and $935 \mathrm{~cm}^{-1}$ correspond to the libration of $\mathrm{OH}$ bonds in $\mathrm{Al}-\mathrm{OH}$ groups. The first vibration is related to internal hydroxyls and the second one corresponds to hydroxyls on the surface. Finally, the bands observed at 1010, 1035 and $1110 \mathrm{~cm}^{-1}$ are assigned to the stretching vibrations of $\mathrm{Si}-\mathrm{O}$ bonds.

In the $3000-3800 \mathrm{~cm}^{-1}$ domain (Figure 2(b)), the infrared spectra of the studied samples showed the four distinct bands characteristic for kaolinite, corresponding to the stretching vibrations of $\mathrm{Al}_{2} \mathrm{OH}$ in kaolinite. The band at $3620 \mathrm{~cm}^{-1}$ which is very intensive in all samples, corresponds to the stretching vibration of hydroxyls of the median plane of the layer (also called internal hydroxyls) found in both 1:1 and 2:1 minerals. The three other bands respectively at 3653, 3666 and $3695 \mathrm{~cm}^{-1}$ correspond to the stretching vibrations of the hydroxyls located in the interlayer space (also called external hydroxyls). These ones appear only in 1:1 minerals and two forms can be distinguished [19] [20]. The band at $3653 \mathrm{~cm}^{-1}$ is due to an external hydroxyl forming an angle of $76^{\circ}$ with the crystallographic axis $c$. Those at 3666 and $3695 \mathrm{~cm}^{-1}$ are due to the coupling of two external hydroxyls, respectively in phase and out of phase.

In addition, the infrared spectra display a band around $3596 \mathrm{~cm}^{-1}$, assigned to Al-OH-Fe stretching according to Delineau et al. [21].

Thermal analyses (Figure 3) confirmed the mineralogical composition of the studied samples. On the thermograms, the endothermic peak of low intensity was observed between $50^{\circ} \mathrm{C}$ and $90^{\circ} \mathrm{C}$, along with a small mass depletion $(0.5 \%$ to $1 \%)$, which correspond to the loss of water molecules adsorbed on mineral surface (hygroscopic water).

A significant endothermic phenomenon between $250^{\circ} \mathrm{C}$ and $300^{\circ} \mathrm{C}$ involving a small mass loss took place for samples LJFF and LJPF. This corresponds to the transformation of goethite to hematite by dehydroxylation [22].

In the range in of $500^{\circ} \mathrm{C}$ to $525^{\circ} \mathrm{C}$, in correlation with temperatures reported by other authors [23]-[25], the thermograms showed an endothermic peak and a strong mass loss, attributed to the loss of structural hydroxyls from the octahedral sheet of the kaolinite [26] [27] upon formation of metakaolinite [28]. 


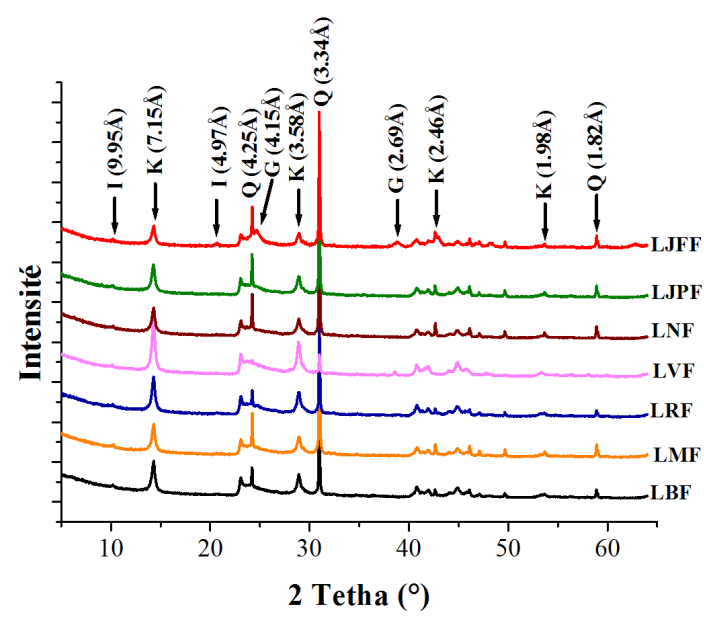

(a)

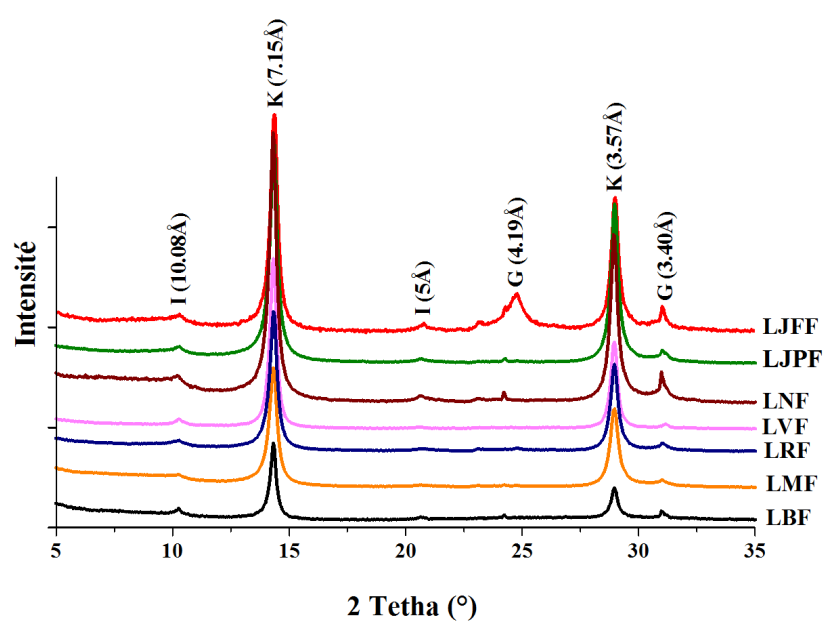

(b)

Figure 1. X-ray patterns of samples $(\lambda=1.7889 \AA)(\mathrm{G}=$ Goethite, $\mathrm{I}=$ Illite, $\mathrm{K}=$ Kaolinite, $\mathrm{Q}=$ Quartz); (a) On powders disorientated for the total rock; (b) By oriented deposits for the fine fraction.

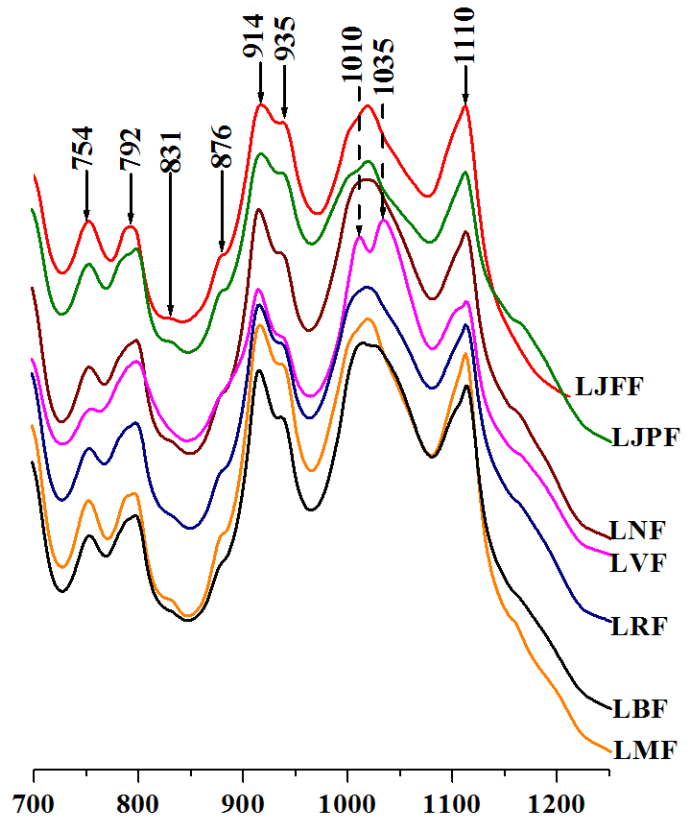

(a)

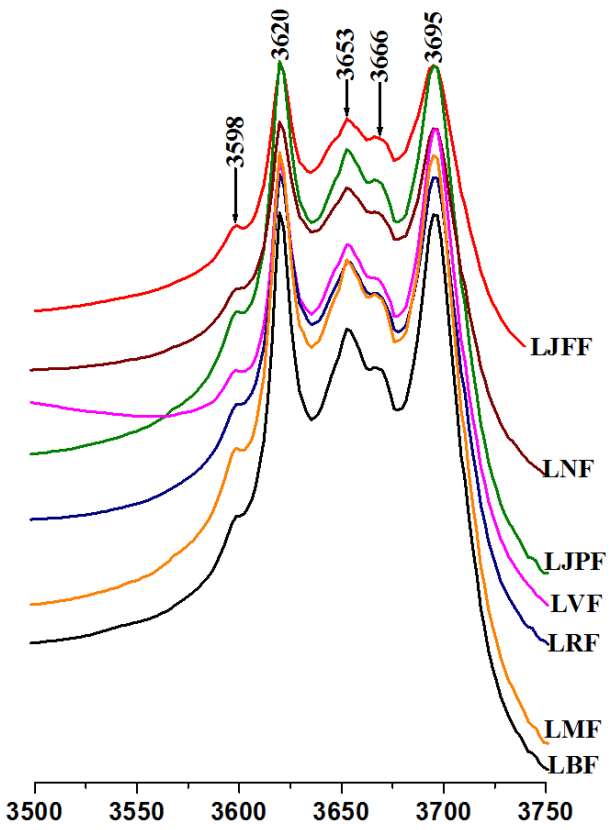

(b)

\section{Figure 2. Infrared spectra of samples.}

The slight modulation observed between $560^{\circ} \mathrm{C}$ and $575^{\circ} \mathrm{C}$ without loss of mass is characteristic of the $(\alpha \leftrightarrow \beta)$ quartz transition [29] [30]. This is confirmed by the presence of an exothermic peak on DTA cooling plot where the reverse action is observed with an exothermic peak at this temperature.

Finally, the exothermic peak toward $955^{\circ} \mathrm{C}$ indicated the transformation of metakaolinite into spinel [31]-[33].

\subsection{Chemical Composition of the Samples}

Chemical analysis reveals that, except LJFF, all samples (Table 1) have relatively similar chemical composition. The $\mathrm{SiO}_{2}$ content range from $45.73 \%$ to $57.05 \%$, those of $\mathrm{Al}_{2} \mathrm{O}_{3}$, from $25.22 \%$ to $34.41 \%$, and trace amount of $\mathrm{Fe}_{2} \mathrm{O}_{3}, \mathrm{TiO}_{2}, \mathrm{Na}_{2} \mathrm{O}, \mathrm{K}_{2} \mathrm{O}$ and $\mathrm{MgO}$ are detected. The sample LJFF shows a high concentration of iron oxide (26.02\%) and lower concentrations of silica (42.71\%) and alumina (18.33\%). 

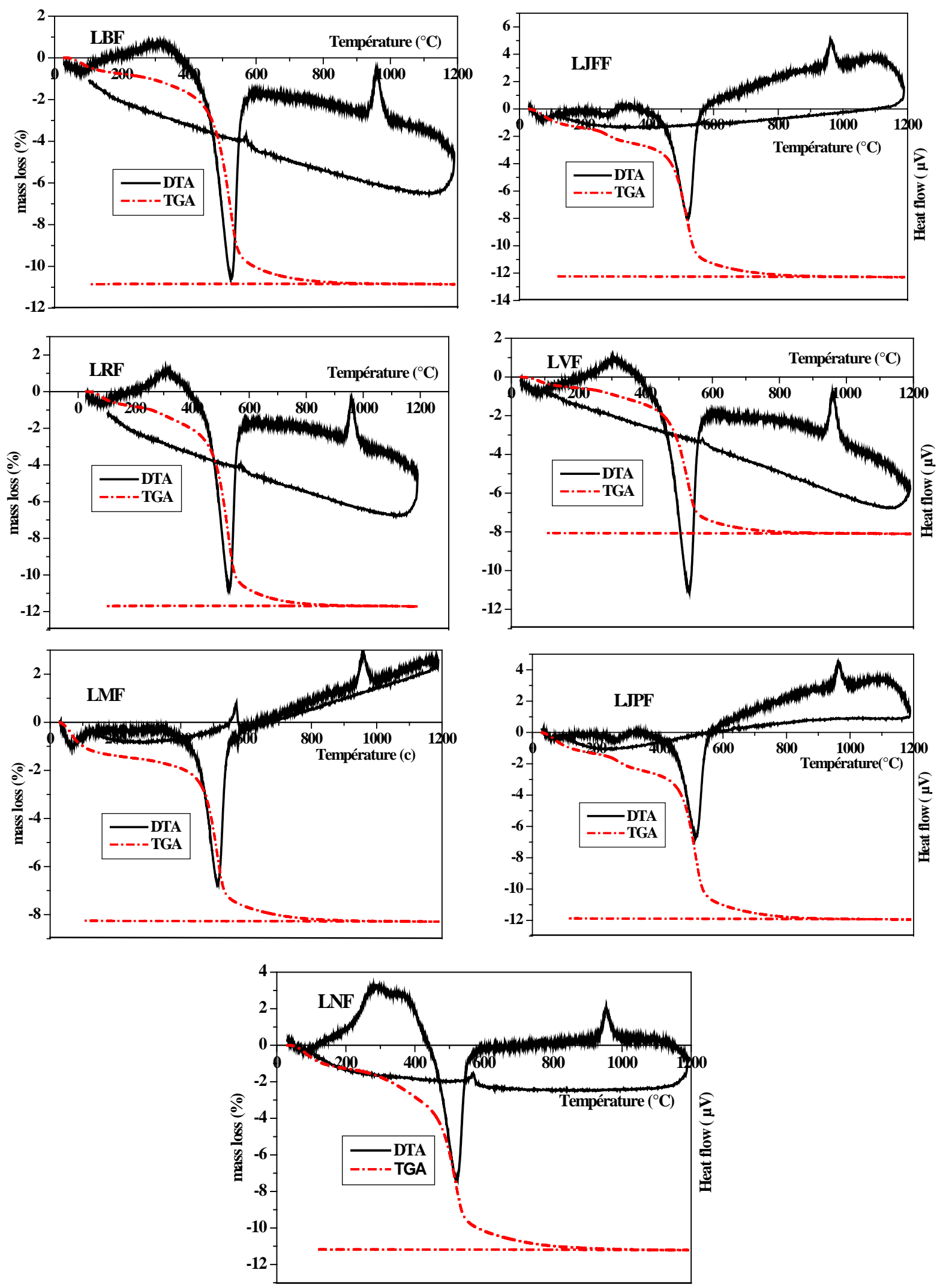

Figure 3. Thermograms of the studied clay samples. 
The elements identified as trace (Table 2) represent the majority of heavy metals, lanthanides and actinides. Usually these trace metals are trapped into oxy hydroxides of Fe (III) or in the clay particles. They can be re-

Table 1. Chemical content in major elements in weight percent (n.d. = not determined).

\begin{tabular}{cccccccccccccc}
\hline Samples & Colour & $\mathbf{S i O}_{2}$ & $\mathrm{Al}_{2} \mathbf{O}_{3}$ & $\mathbf{F e}_{2} \mathbf{O}_{3}$ & $\mathbf{M n O}$ & $\mathbf{M g O}$ & $\mathbf{C a O}$ & $\mathbf{N a}_{2} \mathbf{O}$ & $\mathbf{K}_{2} \mathbf{O}$ & $\mathbf{T i O}_{2}$ & $\mathbf{P}_{2} \mathbf{O}_{5}$ & $\mathbf{H}_{2} \mathbf{O}$ \\
\hline LBF & White & 52.83 & 29.74 & 2.34 & n.d & 0.29 & n.d & 0.11 & 1.17 & 1.06 & 0.08 & 12.03 \\
LRF & Red & 51.06 & 30.18 & 4.48 & 0.00 & 0.22 & n.d & 0.11 & 1.16 & 1.13 & 0.06 & 11.97 \\
LMF & Brown & 56.55 & 25.44 & 4.25 & 0.01 & 0.36 & n.d & 0.08 & 1.01 & 1.10 & 0.08 & 11.46 \\
LVF & Purple & 45.73 & 34.41 & 4.92 & n.d & 0.07 & n.d & 0.06 & 0.57 & 1.12 & 0.09 & 13.12 \\
LJPF & Yellow & 55.33 & 27.81 & 3.97 & 0.00 & 0.24 & n.d & 0.06 & 0.77 & 0.94 & 0.21 & 11.40 \\
LNF & Black & 57.05 & 25.22 & 2.23 & 0.01 & 0.37 & n.d & 0.07 & 0.97 & 1.03 & 0.10 & 13.02 \\
LJFF & Dark-yellow & 42.71 & 18.33 & 26.02 & n.d & 0.14 & n.d & 0.05 & 0.63 & 0.87 & 0.12 & 11.69 \\
\hline
\end{tabular}

Table 2. Chemical composition of trace elements in ppm (n.d. = not determined).

\begin{tabular}{|c|c|c|c|c|c|c|c|c|c|c|c|c|}
\hline Samples & As & Ba & & Be & Cd & \multicolumn{2}{|c|}{ Ce } & Co & Cr & Cs & $\mathrm{Cu}$ & Dy \\
\hline LBF & 7.77 & 313.80 & & 1.28 & 0.13 & \multicolumn{2}{|c|}{120.40} & 3.53 & 163.10 & 7.33 & 19.34 & 4.79 \\
\hline LRF & 12.26 & 299.30 & & 1.24 & 0.15 & \multicolumn{2}{|c|}{53.07} & 3.17 & 160.00 & 5.76 & 12.97 & 2.49 \\
\hline LMF & 4.55 & 21.10 & & 0.98 & 0.30 & \multicolumn{2}{|c|}{30.42} & 29.50 & 94.58 & 0.51 & 83.51 & 7.58 \\
\hline LVF & 18.27 & 159.40 & & 1.13 & 0.14 & \multicolumn{2}{|c|}{90.75} & 3.33 & 173.70 & 2.05 & 7.45 & 2.16 \\
\hline LJPF & 14.67 & 283.90 & & 1.42 & 0.15 & \multicolumn{2}{|c|}{418.10} & 2.38 & 160.70 & 5.10 & 11.90 & 8.09 \\
\hline LNF & 12.53 & 291.70 & & 1.78 & 0.20 & \multicolumn{2}{|c|}{132.50} & 21.24 & 149.60 & 6.39 & 19.24 & 8.09 \\
\hline LJFF & 10.75 & 146.50 & & 1.22 & 0.12 & \multicolumn{2}{|c|}{29.97} & 3.09 & 159.20 & 3.86 & 34.63 & 2.33 \\
\hline Samples & Er & Eu & Ga & Gd & Ge & Hf & Но & In & La & Lu & Mo & Nb \\
\hline LBF & 2.24 & 2.16 & 34.59 & 6.29 & 2.04 & 5.49 & 0.83 & n.d & 50.75 & 0.36 & 1.073 & 12.53 \\
\hline LRF & 1.50 & 0.77 & 37.13 & 2.61 & 1.89 & 5.74 & 0.49 & n.d & 31.88 & 0.29 & 1.21 & 13.32 \\
\hline LMF & 4.41 & 2.01 & 20.18 & 7.05 & 1.76 & 5.06 & 1.57 & n.d & 11.93 & 0.69 & 0.38 & 10.85 \\
\hline LVF & 1.14 & 0.96 & 40.35 & 2.73 & 1.57 & 5.39 & 0.38 & n.d & 48.98 & 0.20 & 2.64 & 15.79 \\
\hline LJPF & 2.84 & 5.08 & 26.87 & 13.31 & 2.32 & 6.30 & 1.16 & n.d & 185.60 & 0.36 & 0.58 & 11.20 \\
\hline LNF & 3.75 & 3.16 & 28.66 & 10.29 & 2.17 & 6.70 & 1.43 & n.d & 53.53 & 0.54 & 1.03 & 13.45 \\
\hline LJFF & 1.43 & 0.63 & 22.28 & 2.25 & 1.79 & 4.64 & 0.48 & n.d & 17.35 & 0.26 & 0.55 & 10.78 \\
\hline Samples & Nd & \multicolumn{2}{|l|}{$\mathrm{Ni}$} & $\mathbf{P b}$ & Pr & $\mathbf{R b}$ & Sb & Sm & Sn & Sr & Ta & $\mathbf{T b}$ \\
\hline LBF & 49.81 & \multicolumn{2}{|l|}{22.52} & 17.98 & 13.46 & 62.08 & 0.59 & 9.29 & 2.79 & 88.88 & 1.14 & 0.91 \\
\hline LRF & 18.80 & \multicolumn{2}{|l|}{23.19} & 18.91 & 5.53 & 56.74 & 0.62 & 3.24 & 2.90 & 71.36 & 1.19 & 0.41 \\
\hline LMF & 21.34 & 52.18 & & 4.65 & 4.49 & 13.05 & 0.21 & 6.11 & 2.19 & 274.1 & 0.89 & 1.20 \\
\hline LVF & 29.11 & 25.47 & & 29.98 & 9.25 & 24.59 & 0.71 & 4.43 & 3.04 & 87.10 & 1.58 & 0.40 \\
\hline LJPF & 140.50 & 16.08 & & 100.84 & 41.91 & 46.72 & 0.47 & 23.56 & 2.12 & 131 & 1.00 & 1.76 \\
\hline LNF & 64.59 & 96.75 & & 19.21 & 16.03 & 63.61 & 0.64 & 12.95 & 2.71 & 92.55 & 1.17 & 1.50 \\
\hline LJFF & 12.51 & 14.34 & & 8.66 & 3.44 & 36.81 & 0.426 & 2.47 & 2.02 & 31.58 & 0.95 & 0.37 \\
\hline Samples & Th & & $\mathbf{T m}$ & $\mathbf{U}$ & $\mathbf{V}$ & & $\mathbf{W}$ & $\mathbf{Y}$ & $\mathbf{Y b}$ & ZI & & $\mathrm{Zr}$ \\
\hline LBF & 9.2 & & 0.33 & 1.85 & 103.1 & & 1.73 & 20.00 & 2.22 & 33. & & 196.6 \\
\hline LRF & 9.8 & & 0.24 & 1.95 & 108.8 & & 1.94 & 13.63 & 1.72 & 37. & & 207.2 \\
\hline LMF & 0.8 & & 0.67 & 0.39 & 259.3 & & n.d & 44.02 & 4.39 & 91. & & 213.4 \\
\hline LVF & 13.0 & & 0.18 & 2.28 & 150.2 & & 1.98 & 9.89 & 1.26 & 34. & & 194.6 \\
\hline LJPF & 8.3 & & 0.37 & 2.11 & 151.7 & & 1.40 & 24.56 & 2.35 & 26. & & 246 \\
\hline LNF & 9.1 & & 0.55 & 1.96 & 97.54 & & 1.66 & 36.75 & 3.63 & 39. & & 259.2 \\
\hline LJFF & 7.5 & & 0.23 & 3.98 & 90.96 & & 1.31 & 13.60 & 1.64 & 66. & & 178.7 \\
\hline
\end{tabular}


tained by sorption or coprecipitation. Samples contain some other heavy metals (cobalt, copper, molybdenum, zinc).

\subsection{Quantitative Mineral Composition}

Determination of the minerals in a complex sample (Table 3) can be estimated from qualitative mineralogical composition revealed by X-ray diffraction (Figure 1) and infrared spectroscopy (Figure 2), assuming an ideal composition of each of these minerals. For this purpose, the method developed by Njopwouo [34] and Yvon et $a l$. [35] was carried out. This method consists in writing for every element (a) the following relation:

$T a=\sum_{i=1}^{n} M \boldsymbol{i} \times P \boldsymbol{i}(a)$

$T a=T a \%$ content in element " $a$ " in the material;

Mi: mineral content " $i$ " in the material;

$P i(a)$ : proportion of the element " $a$ " in the mineral " $i$ " (evaluated from the ideal formula).

The mineralogical composition was determined on the basis of following assumptions:

The contents of illite, goethite and rutile are respectively determined from the percentage of chemical analysis of $\mathrm{K}_{2} \mathrm{O}, \mathrm{TiO}_{2}$ and $\mathrm{Fe}_{2} \mathrm{O}_{3}$.

Kaolinite is determined by the difference between the percentage of chemical analysis of $\mathrm{Al}_{2} \mathrm{O}_{3}$ and the proportion of $\mathrm{Al}_{2} \mathrm{O}_{3}$ corresponding to illite;

In all samples, kaolinite is the main mineral with content varying from $41 \%$ to $84 \%$. Samples contain significant amounts of quartz (14\% - 27\%), except Sample LVF (4.3\%) in which kaolinite is great amount. Goethite is present in low concentrations (2\% - 5\%) for all samples except LJFF (26\%). The high value for this sample is in agreement with the high amount in $\mathrm{Fe}_{2} \mathrm{O}_{3}$ obtained in the chemical analysis. All samples contain also illite (4\% $10 \%)$ associated with the rutile trace $(1 \%)$.

The different colors of samples of clay materials are generally due to the iron oxidation state they contain. The red and yellow colors observed for some samples imply the presence of iron oxidized form (Fe III). The high content of goethite in the sample LJFF justifies its dark yellow color. For sample LVF, purple color (mixture of blue and red) can be due to the coexistence of ferric and ferrous iron in its composition, because the latter is responsible for the blue color. These observations correlate with the study carried out on their iron speciation by Mössbauer spectroscopy [36]. The mineral content of sample LNF is almost identical to that of most other samples. Only its appearance can justify the fact that it is not consumed internally.

\subsection{Crystallinity of the Minerals}

The crystallinity of the samples was evaluated using data from the X-ray diffraction, differential thermal analysis and infrared spectra. The different parameters to assess the crystallinity are shown in Table 4.

The number of layers (L) varied from 28 to 43, the crystalline index R2 (defined by Case et al. [37]) from

Table 3. Potential mineralogical composition of samples.

\begin{tabular}{|c|c|c|c|c|c|c|}
\hline \multicolumn{7}{|c|}{ Mineralogical composition (\%) } \\
\hline & Rutile & Goethite & Illite & Kaolinite & Quartz & TOTAL \\
\hline LBF & 1.06 & 2.34 & 9.73 & 66.79 & 17.06 & 96.98 \\
\hline LJPF & 1.0 & 3.97 & 6.44 & 65.02 & 21.87 & 98.3 \\
\hline LRF & 1.13 & 4.48 & 9.66 & 67.98 & 14.77 & 98.02 \\
\hline LVF & 1.12 & 4.92 & 4.74 & 83.61 & 4.3 & 98.69 \\
\hline LMF & 1.10 & 4.25 & 8.38 & 57.06 & 25.96 & 96.75 \\
\hline LJFF & 1.0 & 26.02 & 5.28 & 41.86 & 20.67 & 94.83 \\
\hline LNF & 1.03 & 2.23 & 8.11 & 56.77 & 26.71 & 94.85 \\
\hline
\end{tabular}


Table 4. Crystallinity parameters.

\begin{tabular}{cccccccc}
\hline Samples & $\mathbf{L}$ & $\mathbf{R} 2$ & $\mathbf{I c}$ & $\mathbf{T}_{\text {endo }}\left({ }^{\circ} \mathbf{C}\right)$ & $\mathbf{S . R}$ & $\mathbf{P 1}$ & $\mathbf{P 2}$ \\
\hline $\mathbf{L B F}$ & 39 & 0.92 & 1.32 & 521 & 2,21 & $-3.2 \times 10^{-3}$ & 0.95 \\
$\mathbf{L J P F}$ & 43 & 0.99 & 0.97 & 509 & 2,33 & $-5.7 \times 10^{-3}$ & 0.92 \\
$\mathbf{L R F}$ & 32 & 0.96 & 1.00 & 524 & 1,72 & $-4.5 \times 10^{-3}$ & 0.96 \\
$\mathbf{L V F}$ & 35 & 0.84 & 0.61 & 525 & 2,29 & $-3.4 \times 10^{-3}$ & 0.96 \\
$\mathbf{L M F}$ & 39 & 0.98 & 0.99 & 507 & 2,33 & $-5.1 \times 10^{-3}$ & 0.94 \\
$\mathbf{L J F F}$ & 28 & 0.96 & 1.00 & 515 & 2,31 & $-5.5 \times 10^{-3}$ & 0.73 \\
LNF & 35 & 1.06 & 1.13 & 517 & 1,97 & $-4.5 \times 10^{-3}$ & 0.94 \\
\hline
\end{tabular}

0.84 to 1.06 and the index of Hinkley (Ic) [38], from 0.61 to 1.32 .

These parameters calculated from the diffraction patterns indicated that the samples were moderately crystallized. Indeed, the well-crystallized kaolinites were characterized by a large number of layers ( $\mathrm{L} \approx 75$ layers), low crystallinity and Hinkley indices.

The lower crystallinity of samples is also demonstrated by the temperature (Tendo) and the slope ratio (S.R), reflecting the asymmetry of the peak of dehydroxylation on the thermograms. The well-ordered kaolinite is characterized by a dehydroxylation temperature higher than $575^{\circ} \mathrm{C}$ [39] and a low slop ratio, around the unity [20].

The dehydroxylation temperature and the slope ratio determined for the samples analysed are respectively in the average $515^{\circ} \mathrm{C}$ and 2.15 .

Stretching bands of vibration of the hydroxyl groups (domain $3500-3700 \mathrm{~cm}^{-1}$ ) are also sensitive to the crystallinity of the kaolinite. When this mineral is well crystallized, the four bands are very distinct. On the other side, the two intermediate bands $\left(3653 \mathrm{~cm}^{-1}\right.$ and $\left.3666 \mathrm{~cm}^{-1}\right)$ are summarized in a broad band [40] as it is more or less the case in the infrared spectra.

Indices P1 and P2 respectively calculated from bending modes (938 and $915 \mathrm{~cm}^{-1}$ ) and stretching modes (3655 and $3672 \mathrm{~cm}^{-1}$ ) of the hydroxyl groups also showed that the samples are moderately crystallized. The values are negative for P1 while those of P2 are less than one. A well crystallized kaolinite is characterized by a positive value of P1 with a P2 value closer to the unity [20].

\subsection{Particle Size Distribution and Texture of the Samples}

The particle size distribution curves (Figure 4) showed a magnitude in the order of meshes corresponding to $90 \%, 75 \%, 50 \%$ and $10 \%$ of the passing through particles respectively noted $d_{90}, d_{75}, d_{50}$ and $d_{10}$ (Table 5). The samples are characterized by relatively sharpness of grains, $90 \%$ of the passing through particles have an average diameter less than 24 microns and 50\% have an average diameter less than 8 microns.

The analysis of the figure and the table shows that the samples LRF and LBF are those containing the fine particles while LJPF and LVF contain less. Generally, samples LRF and LBF are the most consumed, the sharpness of their grains could involve a high absorption capacity.

The specific surface area values obtained for the samples are generally between 35 and $43 \mathrm{~m}^{2} \cdot \mathrm{g}^{-1}$ (Table 6) and slightly higher than the values generally observed $\left(10\right.$ to $\left.30 \mathrm{~m}^{2} \cdot \mathrm{g}^{-1}\right)$ for a kaolinite [41] [42].

These values are related in part to the presence of goethite observed by X-ray diffraction [29] [30] [42] [43]. The low value of specific surface area $\left(26.8 \mathrm{~m}^{2} \cdot \mathrm{g}^{-1}\right)$ for the sample LVF is explained by its low rate of fine grains. The specific surface areas observed are large therefore these samples have a high adsorption capacity. They can be used in the medical purposes. Indeed, the clays used in protecting the intestinal mucosa or in the pharmaceutical industry must have a large specific surface and high absorption capacity [4].

\subsection{Evaluation of the Edibility of the Clays}

The edibility of clays on the basis of their healing properties is based among other things, on their protective action and their ability to inhibit the aggressive action of pathogens that cause dysfunctionning of the gastrointestinal mucosa. 


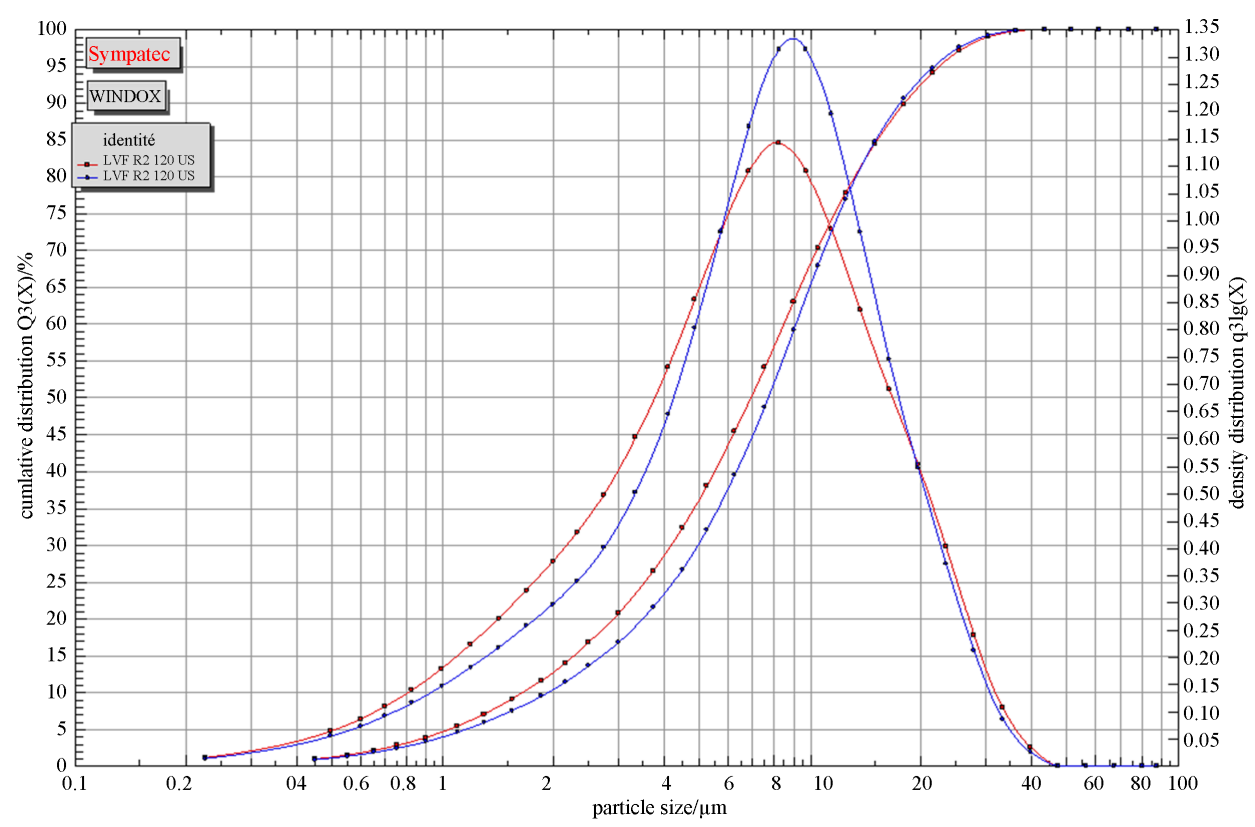

Figure 4. Granular distribution of the sample LVF.

Table 5. Value of $d_{90}, d_{75}, d_{50}$ and $d_{10}$.

\begin{tabular}{|c|c|c|c|c|c|}
\hline \multicolumn{6}{|c|}{ Particle size $(\mu \mathrm{m})$} \\
\hline & $d_{90}$ & $\mathbf{d}_{75}$ & $d_{50}$ & $\mathbf{d}_{25}$ & $d_{10}$ \\
\hline LBF & 23.45 & 11 & 4.5 & 1.75 & 0.83 \\
\hline LJPF & 14.74 & 8.5 & 5.7 & 3.25 & 1.35 \\
\hline LRF & 13.32 & 7.5 & 4.46 & 2.25 & 1.13 \\
\hline LVF & 17.72 & 11.6 & 7.69 & 4 & 1.94 \\
\hline LMF & 20.85 & 11.6 & 5.12 & 2 & 0.93 \\
\hline LJFF & 14.09 & 8.5 & 5.08 & 2.25 & 1.15 \\
\hline LNF & 19.83 & 11.6 & 5.04 & 2.4 & 1.18 \\
\hline
\end{tabular}

Table 6. Specific surface area $\left(\mathrm{S}_{\mathrm{BET}}\left(\mathrm{m}^{2} \cdot \mathrm{g}^{-1}\right)\right)$.

\begin{tabular}{ccccccccc}
\hline & LBF & LJPF & LRF & LVF & LMF & LJFF & LNF \\
\hline $\mathbf{S}_{\text {BET }}\left(\mathrm{m}^{2} \cdot \mathrm{g}^{-1}\right)$ & $\mathbf{3 5 . 7}$ & 35.8 & 35.05 & 26.8 & 39.8 & 43 & 35.6 & \\
$\mathbf{F e}_{2} \mathbf{O}_{3}(\%)$ & 2.34 & 3.97 & 4.48 & 4.92 & 4.25 & 26.02 & 2.23 \\
\hline
\end{tabular}

Two modes of action govern these benefits. First, the adsorption of the "aggressors" or their toxic secretions, and also the change of the thickness and rheological properties of the mucus, reinforcing the natural defense of the gastrointestinal mucosa [8].

The clays of the Bingerville quarry, made up of kaolinite and illite as clay minerals and other minerals including goethite, rutile and quartz, are characterized by relatively fine grain size, high specific area and thermal stability. These characteristics have already been described as suitable for healing properties therefore, their edibility [6] [7]. Indeed, all minerals constituting the clay materials are not toxic and have healing properties. Kaolinite, the main mineral is one of the most consumed clays [44]. It is used as an excipient in pharmaceutical preparations [45]. 
The relatively high specific surface areas $\left(26-43 \mathrm{~m}^{2} \cdot \mathrm{g}^{-1}\right)$ should give to these clays a good adsorption capacity. They may be used in the treatment of certain poisonings by trapping toxins [46], pesticides [47], microorganisms [48], gas [8], and food allergy [49], thus limiting their actions.

The fineness of the clay particles should give good reactivity notably strong bioadhesive properties. They can exert a stabilizing effect on the mucosal barrier, providing protection against different "aggressors" of the gastrointestinal mucosa [8].

Chemical analysis shows that samples contain numerous mineral elements including alkaline, alkaline earth metals, transition metals, lanthanides and actinides. Some of them $(\mathrm{Cu}, \mathrm{Al})$ being important for biological activity when taken up in low quantities and toxic in high dose. Others elements, such as lead, cadmium, arsenic... are toxic. However, their low level in these materials, do not induce serious dangers related to their consumption.

Radioactivity measurements performed on these clay materials [14] have shown that hazards pertaining to radionuclides are negligible.

\section{Conclusion}

Chemical analyses showed that the samples contain many elements as alkalis, heavy metal etc.; some of them are important for biological activity. Mineralogical analysis show that samples consist mainly of kaolinite, illite associated with impurities as quartz, goethite and rutile. No toxic mineral such as fibrous clay was found in the samples investigated. Samples are rich in fine-grain. The specific surface areas observed $\left(26-43 \mathrm{~m}^{2} \cdot \mathrm{g}^{-1}\right)$ are large enough therefore these samples have a high adsorption capacity. They can be used in the treatment of certain poisonings like diarrhea. Besides the microbiological survey to be carried out, it is necessary to sift before all internal use in order to extract possible coarse particles including quartz grains.

\section{Acknowledgements}

This study was carried out in the "Laboratoire Interdisciplinaire des Environnements Continentaux" of Nancy (France). We are therefore grateful to all members of this laboratory for their contribution.

\section{References}

[1] Haussonne, J.-M., Carry, C., Bowen, P. and Barton, J. (2005) Céramiques et verres; Traité des matériaux. Presses Polytechniques et Universitaires Romandes, Lausanne (Suisse), Vol. 16.

[2] Delon, J.F., Liétard, O., Cases, L.M., Richard, M., Sauret, G. and Maume, J.P. (1982) Possibilités d’emploi des Kaolins des Charentes dans le couchage des papiers et cartons. Bulletin de Mineralogie, 105, 571-581.

[3] Ouachem, D. and Soltane, M. (2009) L'argile: Une alternative biologique dans l'alimentation des ruminants, Filière Ovine et Caprine, $n^{\circ} 29-3^{\text {ième }}$ trimestre.

[4] Carretero, M.I. (2002) Clay Minerals and Their Beneficial Effects upon Human Health. A Review. Applied Clay Science, 21, 155-163. http://dx.doi.org/10.1016/S0169-1317(01)00085-0

[5] Viseras, C., Aguzzi, C., Cerezo, P. and Lopez-Galindo, A. (2007) Uses of Clay Minerals in Semisolid Health Care and Therapeutic Product. Applied Clay Science, 36, 37-50. http://dx.doi.org/10.1016/j.clay.2006.07.006

[6] Gomes, C. and Silva, J. (2001) Beach Sand and Bentonite of Porto Santo Island: Potentialities for Applications in Geomedicine. In: Gomes, C. and Silva, J., Eds., O Liberal, Camara de Lobos, Madeira, 60.

[7] Gomes, C. and Silva, J. (2006) Minerals and Human Health/Os Minerais e a Saúde Humana. In: Gomes, C. and Silva, J., Eds., Litografia da Maia, Maia, 300.

[8] Droy-Lefaix, M.T. and Tateo, F. (2006) Clays and Clay Minerals as Drugs, In: Bergaya, F., Theng, B.K.G., and Lagaly, G., Eds., Handbook of Clay Scienc Developments in Clay Science, 1, Elsevier, Amsterdam, 743-753.

[9] Williams, L.B., Holland, M., Eberl, D.D., Brunet, T. and Brunet de Courrsou, L. (2004) Killer Clays! Natural Antibacterial Clay Minerals. Mineralogical Society Bulletin, 139, 3-8.

[10] Tong, G., Yulong, M., Peng, G. and Zirong, X. (2005) Antibacterial Effects of the Cu(II)-Exchanged Montmorillonite on Escherichia coli K88 and Salmonella choleraesuis. Veterinary Microbiology, 105, 113-122. http://dx.doi.org/10.1016/j.vetmic.2004.11.003

[11] Ma’or, Z., Henis, Y., Along, Y., Orlov, E., Sorensen, K.B. and Oren, A. (2006) Antimicrobial Properties of Dead Sea Black Mineral Mud. International Journal of Dermatology, 45, 504-511.

http://dx.doi.org/10.1111/j.1365-4632.2005.02621.x 
[12] Haydel, S.E., Remineh, C.M. and Williams, L.B. (2008) Broad-Spectrum in Vitro Antibacterial Activities of Clay Minerals against Antibiotic-Susceptible and Antibiotic-Resistant Bacteria Pathogens. Journal of Antimicrobial Chemotherapy, 61, 353-361. http://dx.doi.org/10.1093/jac/dkm468

[13] Magana, S.M., Quintana, P., Aguilar, D.H., Toledo, J.A., Angeles-Chavez, C., Cortes, M.A., Leon, L., Freile-Pelegrın, Y., Lopez, T. and Torres Sanchez, R.M. (2008) Antibacterial Activity of Montmorillonites Modified with Silver. Journal of Molecular Catalysis A: Chemical, 281, 192-199. http://dx.doi.org/10.1016/j.molcata.2007.10.024

[14] Coulibaly, V., Sei, J., Kouamé, N., Koua, A.A., Oyetola, S. and Brun, S. (2013) Measurement of Natural Radioactivity in the Clays Consummated in Côte d'Ivoire Using Gamma-Ray Spectrometry. Journal of Applied Sciences, 13, 140146.

[15] Taste, J.P. (1979) Environnements sédimentaires et structuraux quaternaires du littoral du golfe de guinée (Côte d’Ivoire, Togo et Benin). Thèse Doctorat d'Etat, Université Bordeaux I, Bordeaux, 175 p.

[16] Farmer, V.C. (1974) The Layer Silicates. In: Farmer, V.C., The Infrared Spectra of Minerals, Mineralogical Society, London, 331-363.

[17] Russell, J.D., Farmer, V.C. and Velde, B. (1970) Replacement of OH by OD in Layer Silicates and Identification of the Vibrations of These Groups in Infrared Spectra. Mineralogical Magazine, 37, 869-879. http://dx.doi.org/10.1180/minmag.1970.037.292.01

[18] Mendelovici, E., Yariv, S.H. and Villalba, R. (1979) Iron-Bearing Kaolinite in Venezuelan Laterite. I. Infrared Spectroscopy and Chemical Dissolution Evidence. Clay Minerals, 14, 323-331. http://dx.doi.org/10.1180/claymin.1979.014.4.08

[19] Giese, R.F. and Datta, P. (1973) Hydroxyl Orientation in Kaolinite, Dickite and Nacrite. American Mineralogist, 58, 471-479.

[20] Cases, J.-M., Liétard, O., Yvon, J. and Delon, J.-F. (1982) Etude des propriétés cristallochimiques, morphologiques, superficielles des kaolinites désordonnées. Bullettin Minéralogique, 105, 439-455.

[21] Delineau, T., Allard, T., Muller, J.-P., Barres, O., Yvon, J. and Cases, J.M. (1994) FTIR Reflectance vs. EPR Studies of Structural Iron in Kaolinites. Clays and Clay Minerals, 42, 308-320. http://dx.doi.org/10.1346/CCMN.1994.0420309

[22] Fan, H., Song, B. and Li, Q. (2006) Thermal Behavior of Goethite during Transformation to Hematite. Materials Chemistry and Physics, 98, 148-153. http://dx.doi.org/10.1016/j.matchemphys.2005.09.005

[23] Singh, B. and Gilkes, R.J. (1992) Properties of Soil Kaolinite from South-Western Australia. Journal of Soil Science, 43, 654-667. http://dx.doi.org/10.1111/j.1365-2389.1992.tb00165.x

[24] Melo, V.F., Singh, B., Schaefer, C.E.G.R., Novais, R.F. and Fontes, M.P.F. (2001) Chemical and Mineralogical Properties of Kaolinite-Rich Brazilian Soils. Soil Science Society of America Journal, 65, 1324-1333. http://dx.doi.org/10.2136/sssaj2001.6541324x

[25] Hart, R.D., Gilkes, R.J., Siradz, S. and Singh, B. (2002) The Nature of Soil Kaolins from Indonesia and Western Australia. Clays and Clay Minerals, 50, 198-207. http://dx.doi.org/10.1346/000986002760832793

[26] Toussaint, F., Fripiat, J.J. and Gastuche, M.C. (1963) Dehydroxylation of Kaolinite. I: Kinetics. The Journal of Physical Chemistry, 67, 26-30. http://dx.doi.org/10.1021/j100795a007

[27] Ortega, A., Rouquérol, F., Akhouayri, S., Laureiro, Y. and Rouquérol, J. (1993) Kinetical Study of the Thermolysis of Kaolinite between $30{ }^{\circ} \mathrm{C}$ and $1000{ }^{\circ} \mathrm{C}$ by Controlled Rate Evolved Gas Analysis. Applied Clay Science, 8, $207-214$. http://dx.doi.org/10.1016/0169-1317(93)90038-3

[28] Bellotto, M., Gualtieri, A., Artioli, G. and Clark, S.M. (1995) Kinetic Study of the Kaolinite-Mulliteréaction Sequence. Part I: Kaolinite Dehydroxylation. Physics and Chemistry of Minerals, 22, 207-214. http://dx.doi.org/10.1007/BF00202253

[29] Jouenne, C.A. (1990) Traité de céramiques et Matériaux Minéraux. Edition Septima, Paris.

[30] Brown, G. and Brindley, G.W. (1984) Crystal Structures of Clay Minerals and Their X-Ray Identification. 2nd Edition, Mineralogical Society, London, 305-360.

[31] Okada, K., Otsuka, N. and Ossaka, J. (1986) Characterization of Spinel Phase Formed in the Kaolinite-Mullite Thermal Sequence. Journal of the American Ceramic Society, 69, 251-253. http://dx.doi.org/10.1111/j.1151-2916.1986.tb07353.x

[32] Srikrishna, K., Thomas, G., Martinez, R., Corral, M.P., De Aza, S. and Moya, J.S. (1990) Kaolinite-Mullitereactionseries: A TEM Study. Journal of Materials Science, 25, 607-612. http://dx.doi.org/10.1007/BF00714083

[33] Gualtieri, A., Belloto, M., Artioli, G. and Clark, S.M. (1995) Kinetic Study of the Kaolinite-Mullite Reaction Sequence. Part II: Mullite Formation. Physics and Chemistry of Minerals, 22, 215-222. http://dx.doi.org/10.1007/BF00202254

[34] Njopwouo, D. (1984) Minéralogie et physico-chimie des argiles de Bomkoul et de Balengou (Cameroun). Utilisation 
dans la polymérisation du styrène et dans le renforcement du caoutchouc naturel. Thèse de doctorat, d’État de l’Université de Yaoundé, Yaoundé.

[35] Yvon, J., Baudracco, J., Cases, J.M. and Weiss, J. (1990) Eléments de minéralogie quantitative en micro-analyse des argiles. Matériaux argileux, structures, propriétés et applications. SFMC., Paris.

[36] Coulibaly, V., Sei, J., Oyetola, S., Sougrati, M.T. and Jumas, J.C. (2012) Iron Speciation in the Clays Consummated in Côte d’Ivoire: A Transmission Mössbauer Spectroscopy Study. Asian Journal of Applied Sciences, 5, 460-472. http://dx.doi.org/10.3923/ajaps.2012.460.472

[37] Liétard, O. (1977) Contribution à l’étude des propriétés physicochimiques cristallographiques et morphologiques des kaolins. Thèse doctorat ès-sciences, INPL, Nancy, $345 \mathrm{p}$.

[38] Hinckley, D.N. (1962) Variability in "Crystallinity” Values among the Kaolin Deposits of the Coastal Plain of Georgia and South Carolina. Proceedings of the 11th National Conference on Clays and Clay Minerals, Ottawa, 13-17 August 1962, 229-235.

[39] Smykatz-Kloss, W. (1974) Differential Thermal Analysis: Application and Result in Mineralogy. Springer Verlag Berlin Heidelberg, New York. http://dx.doi.org/10.1007/978-3-642-65951-5

[40] Russell, J.D. and Fraser, A.R. (1994) Infrared Methods In-Clay Mineralogy: Spectroscopic and Chemical Determinative Methods. Chapman and Hall, London.

[41] Guyot, J. (1969) Mesure des surfaces spécifiques des argiles par adsorption. Annales Agronomiques, 20, 333-359.

[42] Arias, M., Barral, M.T. and Diaz-Fierros, F. (1995) Effect of Iron and Aluminium Oxides on the Colloidal and Surface Properties of Kaolin. Clays and Clay Minerals, 43, 406-416. http://dx.doi.org/10.1346/CCMN.1995.0430403

[43] Borggaard, O.K. (1982) The Influence of Iron Oxides on the Surface Area of Soil. Journal of Soil Science, 33, $443-449$.

[44] Eaton, J.R. and Eaton. T.M. (1995) Bentonite: Public Ressearch Project: An Educational Compilation of Related Commentaries and Articles. http://eytonsearth.org/bentonite.html

[45] Carretero, M.I. and Pozo, M. (2009) Clay and Non-Clayminerals in the Pharmaceutical Industry. Part I. Excipients and Medical Applications. Applied Clay Science, 46, 73-80. http://dx.doi.org/10.1016/j.clay.2009.07.017

[46] Carnoy, C., Muller Alouf, H., Mullet, C., Droy-Lefaix, M.T. and Simonet, M. (2000) Oral Infection of Mice with Superantigenic Toxic Producing Yersinia pseudo tuberculosis. Effect of Diosmectite. International Journal of Medical Microbiology, 290, 477-482.

[47] Meredith, T.J. and Vale, J.A. (1987) Treatment of Paraquat Poisoning in Man. Methods to Prevent Absorption. Human \& Experimental Toxicology, 6, 49-57. http://dx.doi.org/10.1177/096032718700600108

[48] Lipson, S.M. and Stotzky, G. (1984) Effect of Proteins on Reovirus Adsorption to Clay Minerals. Applied and Environmental Microbiology, 8, 525-530.

[49] Theodorou, V., Fioramonti, J., Droy-Lefaix, M.T., Plique, O., Bueno, L. (1994) Protective Action of Diosmectite Treatment on Digestive Disturbances Induced by Intestinal Anaphylaxis in the Guinea Pig. Alimentary Pharmacology \& Therapeutics, 8, 295-299. http://dx.doi.org/10.1111/j.1365-2036.1994.tb00291.x 
Scientific Research Publishing (SCIRP) is one of the largest Open Access journal publishers. It is currently publishing more than 200 open access, online, peer-reviewed journals covering a wide range of academic disciplines. SCIRP serves the worldwide academic communities and contributes to the progress and application of science with its publication.

Other selected journals from SCIRP are listed as below. Submit your manuscript to us via either submit@scirp.org or Online Submission Portal.
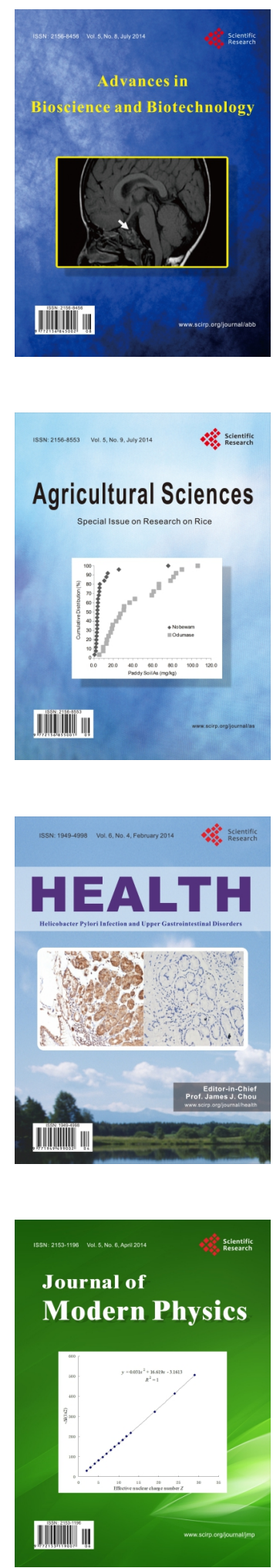
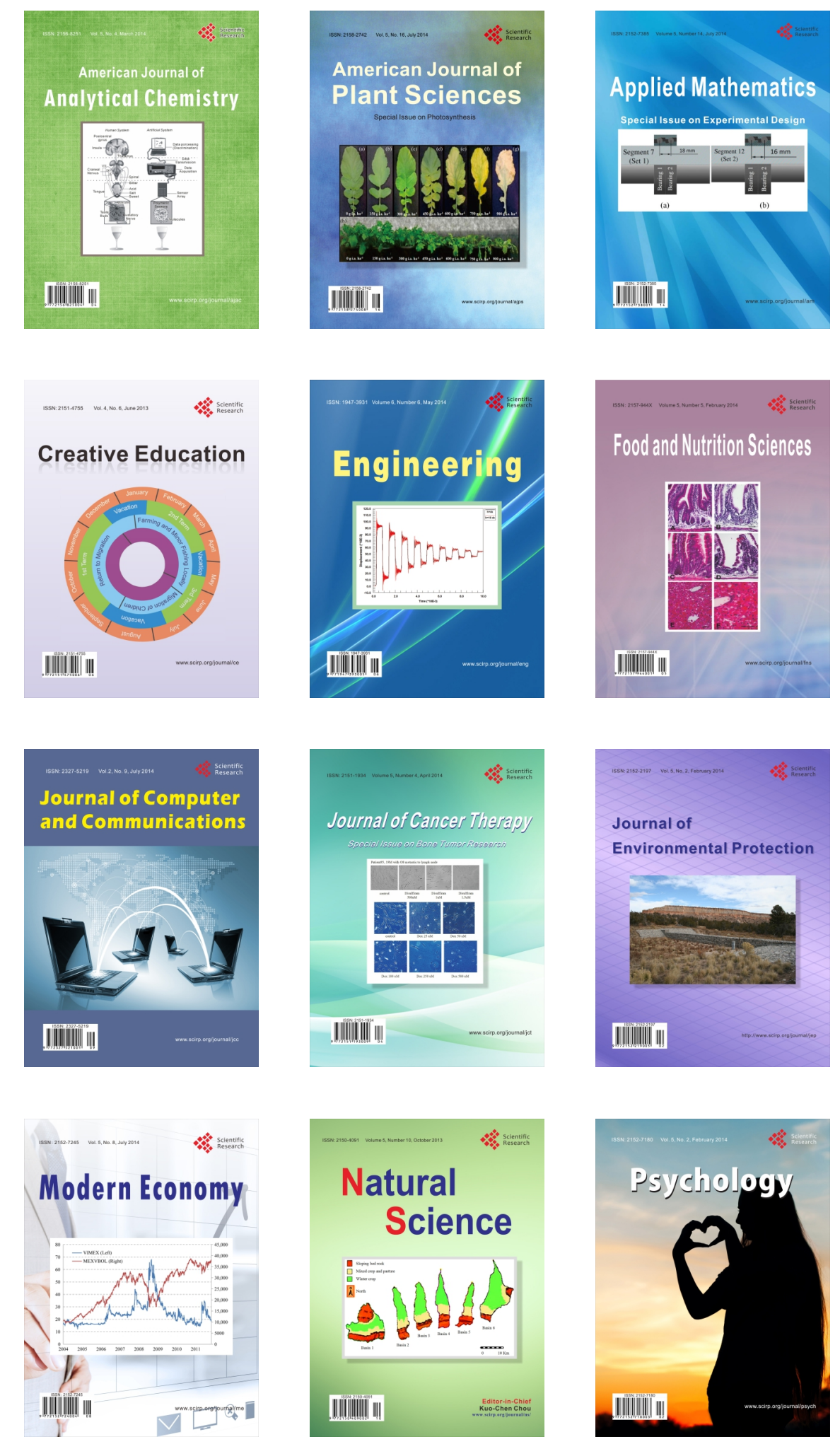